\title{
BIFoR FACE: Water-soil-vegetation-atmosphere research in a temperate deciduous forest catchment, including under elevated $\mathrm{CO} 2$
}

Angus Robert MacKenzie ${ }^{1}$, Stefan Krause ${ }^{2}$, Kris Hart ${ }^{1}$, Richard Thomas ${ }^{1}$, Philip Blaen ${ }^{2}$, R. Hamilton ${ }^{1}$, Giulio Curioni ${ }^{2}$, Susan Quick ${ }^{1}$, Angeliki Kourmouli ${ }^{1}$, David Hannah ${ }^{2}$, Sophie Comer-Warner $^{1}$, Nicolai Brekenfeld ${ }^{1}$, Sami Ullah ${ }^{1}$, and Malcolm Press ${ }^{3}$

${ }^{1}$ University of Birmingham Edgbaston Campus

${ }^{2}$ University of Birmingham

${ }^{3}$ Manchester Metropolitan University

October 1, 2020

A. R. MacKenzie ${ }^{1,2, *}$, S. Krause ${ }^{1,2}$, K. M. Hart ${ }^{1}$, R. M. Thomas ${ }^{1,3}$, P. J. Blaen ${ }^{1,4}$, R.L. Hamilton ${ }^{1,2}$, G. Curioni $^{1,2}$, S. E. Quick ${ }^{1,2}$, A. Kourmouli ${ }^{1,2}$, D. M. Hannah ${ }^{1,2}$, S. A. Comer-Warner ${ }^{1,2}$, N. Brekenfeld ${ }^{1,2}$, S. Ullah $^{1,2}$ and M. C. Press ${ }^{1,5}$

1. Birmingham Institute of Forest Research, University of Birmingham, Birmingham B15 2TT, UK

2. School of Geography, Earth and Environmental Science, University of Birmingham, Birmingham B15 $2 \mathrm{TT}, \mathrm{UK}$

3. Now at Big Sky Science Ltd, Sutton Coldfield, West Midlands, B72 1SY, UK

4. Now at Yorkshire Water, Chadwick Street, Leeds, LS10 1LJ, UK

5. Now at Manchester Metropolitan University, Manchester, M15 6BH, UK

* Corresponding author:a.r.mackenzie@bham.ac.uk

\section{Keywords}

Soil moisture; stream metabolism; climate change; long-term monitoring

\section{Summary Paragraph}

The ecosystem services provided by forests modulate runoff generation processes, nutrient cycling and water and energy exchange between soils, vegetation and atmosphere. Increasing atmospheric $\mathrm{CO}_{2}$ affects many linked aspects of forest and catchment function in ways we do not adequately understand. Most significantly, global levels of atmospheric $\mathrm{CO}_{2}$ will be around $40 \%$ higher in 2050 than current levels, yet estimates of how water and solute fluxes in forested catchments will respond to increased $\mathrm{CO}_{2}$ are highly uncertain. The Free Air Carbon Enrichment (FACE) facility of the University of Birmingham's Institute of Forest Research (BIFoR) is an intensively monitored forest site specialising in fundamental studies of the response of whole ecosystem patches of mature, deciduous, temperate woodland to elevated $\mathrm{CO}_{2}$. Here, we introduce the facility, situated in a mixed land-use headwater catchment, with a particular focus on its environmental setting and the experimental infrastructure. The facility offers a significant opportunity to advance multi- 
and interdisciplinary understanding at the interfaces of soil, vegetation, hydrosphere and atmosphere under changed atmospheric composition.

\section{Site Description and Methods}

This summary complements online introductory videos (https://tinyurl.com/y3a2hkkx) and draws on the facility 'White Book', which is a live web-document containing extensive details of all the projects undertaken at the facility and details of instrument placement (heights, depths, spatial separation).

\section{The Wood Brook catchment and FACE facility}

The BIFoR FACE facility is situated in a mainly agricultural headwater catchment in the UK drained by the Wood Brook, and consists of the main elevated $\mathrm{CO}_{2}\left(\mathrm{eCO}_{2}\right)$ facility and a number of spatially nested satellite study sites including various forest plantations of different age and management (Figure 1). The facility is in lowland, rural, central England ( $52^{\circ} 48^{\prime} 3.6^{\prime \prime} \mathrm{N}, 2^{\circ} 18^{\prime} 0^{\prime \prime} \mathrm{W}, 106 \mathrm{~m}$ above mean sea level (amsl)), within a patchy landscape typical of most temperate forest settings (Haddad et al., 2015). Wood Brook is a second-order stream with a $3.1 \mathrm{~km}^{2}$ catchment ranging in elevation from 90 to $150 \mathrm{~m}$ amsl (Blaen et al., 2017) and subsequently draining into the River Severn catchment (the most voluminous river in England and Wales). The entire catchment is experiencing drastic land-use changes, having been converted to organic farming since 2019 and herbal lays in replacement of what was previously grass monoculture or arable, in addition to the new forest plantations.

[Figure 1 here]

The BIFoR FACE forest at the bottom of the Wood Brook catchment is a mature deciduous woodland, with dominant (25-m tall) English oak (Quercus robur ) planted around 1850. Sub-dominant (ca. $10 \mathrm{~m}$ tall) species consist of common hazel (Corylus avellana), common hawthorn (Crataegus monogyna), sycamore maple (Acer pseudoplatanus ) and other native species (Hart et al., 2019). Each stem with diameter-atbreast-height greater than $10 \mathrm{~cm}$ has been geolocated and tagged. Centimetre-scale forest structure was measured by a lidar overflight in August 2014 and by terrestrial laser scanning (private communication, Eric Casella, Forest Research, Surrey, UK); this structure establishes the basis for penetration of air, light, and water into the forest canopy.

The central, $\mathrm{eCO}_{2}$ component of BIFoR FACE consists of nine experimental patches of $15 \mathrm{~m}$ radius (Hart et al., 2019). Three 'undisturbed' (or 'ghost') patches have no $\mathrm{CO}_{2}$-dosing infrastructure; three 'control' patches are exposed to ambient $\mathrm{CO}_{2}$ concentrations delivered via the same infrastructure used in the three 'treatment' patches to maintain +150 ppmv above ambient $\mathrm{CO}_{2}$ at all levels of the canopy. Elevated $\mathrm{CO}_{2}$ is maintained during daylight hours from oak bud burst (ca. $1^{\text {st }}$ April) to last leaf fall (ca. $31^{\text {st }}$ October). The $\mathrm{CO}_{2}$-dosing system works well; one-minute running means are within $15 \%$ of target in the treatment plots, with less than $1 \%$ of the time showing deviation above $10 \%$ of the baseline value in the control plots (Hart et al., 2019). The first season with $\mathrm{eCO}_{2}$ was 2017 and the treatment will continue until at least 2026. A parallel study of the effect of nitrogen and phosphorus addition began in 2020 in the forest away from the FACE patches.

Surrounding the BIFoR FACE, the Wood Brook catchment hosts several long-term forest hydrological observatories. In partnership with the estate owners, young mixed-deciduous plantations are subjected to different manipulation treatment including irrigation and fertilisation experiments.

\section{The environmental context}

The climate at the Wood Brook catchment is that of the temperate maritime zone of north-west Europe (Barry and Chorley, 2010). The site-mean annual temperature (MAT) measured between 2016 and 2019 was $10.6 \pm 0.8^{\circ} \mathrm{C}$ and its mean annual precipitation (MAP) was $676 \pm 66 \mathrm{~mm}$. This situates BIFoR FACE well inside the MAT-MAP climate space for temperate forests (Sommerfeld et al., 2018). The catchment is 
within the area covered by the Central England Temperature record, which provides a time series back to 1772 (Parker et al., 1992). The Wood Brook catchment is situated in a Nitrate Vulnerable Zone (European Union Directive 91/676/EEC) with mean nitrate concentrations in the Wood Brook ranging from 5 to 7 mg $\mathrm{N} \mathrm{l}^{-1}$ (Blaen et al., 2017). The contemporary reactive nitrogen deposition from the atmosphere in the catchment is $22 \mathrm{~kg} \mathrm{~N} \mathrm{ha}^{-1} \mathrm{y}^{-1}$ with an ammonium to nitrate deposition ratio of 7:3 (private communication, S. Tomlinson, UK Centre for Ecology \& Hydrology). Deposition of this scale represents less than about 15\% of the total nitrogen nutrition of temperate deciduous forest trees (Rennenberg and Dannenmann, 2015).

\section{Site infrastructure}

The Wood Brook is equipped with two continuous water quality monitoring stations comprising in-stream sensors measuring stage, water temperature, and electrical conductivity continuously (up to every 10 seconds). Sensors to measure further parameters (UV-VIS absorbance, DO, pH, and turbidity) are housed in an insulated kiosk located on the streambank (Blaen et al., 2017a). An ISCO peristaltic pump (Lincoln, $\mathrm{NE}$, USA) passes $1 \mathrm{~L}$ of stream water through these sensors every hour. Continuous stream monitoring is supplemented with campaign-based sampling facilitated by networks of surface water ISCO autosamplers, for instance during tracer tests (Blaen et al., 2017a,b), as well as spatially nested multi-level mini-piezometers installed in the streambed to investigate streambed biogeochemical processes and groundwater-surface water interactions (Comer-Warner et al., 2019, Comer-Warner et al., 2020).

Soil moisture in the main BIFoR FACE facility is monitored by $12 \mathrm{~cm}$ long frequency domain sensors (CS655 by Campbell Scientific, claimed accuracy $\pm 3 \% \mathrm{v} / \mathrm{v}$ for 'typical' soils) installed diagonally from the surface in groups of three spaced $1 \mathrm{~m}$ apart, with two groups in the 'control' and 'treatment' patches and one group in the 'ghost' patches, and monitoring at 15 to 30 min resolution.

In addition, one of the juvenile plantations close to the catchment outlet has been instrumented since 2016 with active fibre-optic distributed temperature sensing (FO-DTS) for measuring soil temperature and soil moisture at a submeter spatial resolution, resulting in 1850 soil temperature and soil moisture sampling locations across the site, ranging from 10-40 cm depths (Ciocca et al., 2020). The retrieval from the FO-DTS has a maximum at $38 \% \mathrm{v} / \mathrm{v}$, a value empirically determined from a soil-specific field calibration against point soil moisture sensors installed adjacent to the fibre-optic cable. The variability shown for the FO-DTS is that for 4 quasi-independent measurements per day at $25 \mathrm{~cm}$ intervals along the fibre-optic cable. Uncertainties of ca. $3-5 \% \mathrm{v} / \mathrm{v}$ have been reported for soil moisture measurements with the DTS technique (Gamage et al. 2018).

Each treatment $\left(\mathrm{eCO}_{2}\right)$ and control experimental patch is ringed by 16 free-standing, climbable, lattice towers that reach $2-3 \mathrm{~m}$ above the local oak canopy; a $17^{\text {th }}$ tower is sited in the centre of each patch. The lattice towers are secured by screw piles; the experimental site contains no concrete foundations or guy wires. Access to the experimental patches is via low-level walkways raised approximately $30 \mathrm{~cm}$ above ground level to prevent compaction. Canopy access above $5 \mathrm{~m}$ is contracted to climbing arborists or achieved using a bespoke canopy access system (CAS) installed from the $17^{\text {th }}$ central tower of each infrastructure array. The CAS is operated by trained staff so that rope access training is not required for researchers. Welfare and simple laboratory facilities are provided. Elevated $\mathrm{CO}_{2}$ dosing, canopy access, and routine monitoring is operated by a team of six technical staff permanently stationed at BIFoR FACE.

Four meteorological masts are located at the periphery of the woodland and a $40 \mathrm{~m}$ 'flux tower' stands towards the downwind end of the wooded area so that its flux 'footprint' is within the forest for the prevailing southwesterly winds. During dosing, true biogeochemical $\mathrm{CO}_{2}$ fluxes are, of course, obscured by the gas released to provide the $\mathrm{eCO}_{2}$ treatment effect but sensible and latent heat fluxes are recorded.

Figure 2 illustrates the flow of data and tissue samples into their permanent repositories. Other equipment (not shown) is deployed ad hoc within specific projects.

[Figure 2 here.] 
To complement the experimental infrastructure in the Wood Brook catchment and BIFoR FACE facility, an integrated groundwater-surface water model has been developed and validated by a combination of flow signatures and applied to investigate stream and subsurface water and energy balance in response to forest shading (Qiu et al., 2019).

\section{Example Results}

\section{Soil moisture dynamics, stream discharge, and water quality in mature forest and young plantation}

Example core data (precipitation and FACE soil water content, discharge and DO) and project-specific data (field-scale soil moisture measured by FO-DTS at $10 \mathrm{~cm}$ ) demonstrate the value of long-term integrated monitoring in ecohydrological observatories such as the Wood Brook catchment (Figure 3).

The variability of the temperate maritime climate is evident: prolonged wetting and drying events with occasional, shorter, high-intensity rainfall events. Signals can take a long time to emerge within such variability, which is a key argument for a long-term experimental platform such as BIFoR FACE. The time series at this relatively early stage suggests that: (i) the plantation is systematically wetter than the neighbouring FACE forest even though the plantation slopes downwards towards FACE; (ii) there is significant spatial variability in the plantation and FACE forest; and (iii) the $\mathrm{eCO}_{2}$ patches are drier than the $\mathrm{aCO}_{2}$ and undisturbed patches. Point (iii) is a result of spatial variability in the forest; the strength of soil moistening due to $\mathrm{eCO}_{2}$, if any is present (cf. Ellsworth, 1999; Drake et al., 2016), remains to be quantified.

Corresponding water levels at the Wood Brook catchment outlet highlight the general "flashiness" of the flow regime with relatively fast responses to precipitation events for a permeable catchment as well as fast recession of flow (Figure 3 bottom). This example time series of one of our monitoring stations also indicates some of the challenges in maintaining consistent quality control throughout long-term observation networks. In addition to data losses induced by power supply failures in Spring 2019, observed values up to early 2019 were an order of magnitude lower than from summer 2019 onwards due to repeated sedimentation of the water level sensor and recurring changes to the channel cross sectional profile that finally led to a relocation of the sensor as indicated in Figure 3. The additional value of continuously monitored water level and water quality data (as highlighted by the example of dissolved oxygen in Fig 3 bottom) extends beyond the ability to observe long-term trends in catchment behaviour in response to land-use changes but also provides opportunity to enhance mechanistic process understanding of in stream metabolism and biogeochemical processing as well as event-based activation of pollution sources (Blaen et al., 2017a).

[Figure 3 here.]

\section{Data protocol and availability}

All projects form part of the overall collaborative effort to understand catchment behaviour and forest form and function, and all facility users sign a data protocol to that effect. The BIFoR FACE science community believe and advocate transparency in science, assured through open data after an agreed period of privileged use.

The facility is supported by a full-time data manager (author GC), responsible for tracking all data and tissue samples. The data is available upon request; an open data repository for a subset of core data is under construction.

The continuous streams of data are handled by a suite of dataloggers and a local LAN network which allows data to be saved on the BIFoR FACE facility server (Figure 2). A back-up server located on site in a separate building stores a daily image of the primary server. Data is transferred daily to the University of Birmingham servers and the raw and processed data (i.e. organised in a consistent format and cleared of evident issues) are stored separately to improve resilience. Non-continuous data collected by researchers 
is stored in the University of Birmingham servers and handled directly between researchers and the data manager.

All tissue is recorded when sampled and a chain-of-custody initiated using Pro-curo. Quenching of biological samples to $-70^{\circ} \mathrm{C}$ is accomplished on-site using a dry shipper (BioTrex-10, Statebourne Cryogenics, Tyne \& Wear, UK), avoiding the need for transporting liquid nitrogen. Short-term tissue storage at $5^{\circ} \mathrm{C}$ and -20 ${ }^{\circ} \mathrm{C}$ can be accommodated on-site, but the permanent tissue bank resides at the University of Birmingham Edgbaston campus.

In summary, BIFoR FACE is an ambitious field facility designed primarily to measure the wholesystem response of mature temperate forest to elevated $\mathrm{CO}_{2}$, but suitable for a wide range of complementary catchment studies. The facility is highly collaborative in nature and welcomes partners11https://www.birmingham.ac.uk/research/bifor/get-involved/index.aspx who wish to contribute as part of a multidisciplinary Community of Practice.

\section{Acknowledgments}

We very gratefully acknowledge support from the JABBS Trust, Norbury Park Estate, The John Horseman Trust, Ecological Continuity Trust, NERC (grants NE/S015833/1, NE/P003486/1, NE/N020502/1; NE/T000449/1; NE/T012323/1), and the University of Birmingham. The soil moisture FO-DTS system installation was led by Francesco Ciocca while holding joint positions at the University of Birmingham and at Silixa Ltd. (London, UK).

The BIFoR FACE facility cannot run without the dedicated support of its operations team (currently; Nicholas Harper, Peter Miles, Thomas Downes, Gael Denny and Robert Grzesik, formerly; Gary McClean and Anna Gardner). Foundational contributions to the design and implementation of the facility were made by Michael Tausz and Sabine Tausz-Posch. The FACE facility $\mathrm{eCO}_{2}$ treatment uses the system designed by John Nagy and installed by Keith Lewin, both of Brookhaven National Lab, USA. We acknowledge the considerable scientific input of visiting fellows (David Ellsworth, Kristine Crous, Debbie Hemming, Rich Norby, Theresa Blume and Mantha Phanikumar) and former researchers (Will Allwood, Alex Poynter, Elizabeth Hamilton). We gratefully acknowledge strategic guidance from BIFoR Directors (Rob Jackson, Jerry Pritchard, and Nicola Spence) and the Science Committee (Christine Foyer, Vincent Gauci, Francis Pope, and Estrella Luna Diez).

\section{References}

Barry, R. G., and Chorley, R. J. (2010) Atmosphere, Weather and Climate, $9^{\text {th }}$ ed., Routledge, London.

Blaen, P., K. Khamis, C. Lloyd, S. Comer-Warner, F. Ciocca, R. M. Thomas, A. R. MacKenzie, Stefan Krause (2017a), High-frequency monitoring of catchment nutrient exports reveals highly variable storm-event responses and dynamic source zone activation, J. Geophys. Res-Biogeosciences, 10.1002/2017JG003904

Blaen P., Brekenfeld N., Comer-Warner S., Krause S. (2017b). Multitracer Field Fluorometry: Accounting for Temperature and Turbidity Variability during Stream Tracer Tests. Water Resources Research, 53,https://doi.org/10.1002/2017WR020815.

Ciocca F., Abesser C., Findlay J., Chalari A., Mondanos M., Hannah D.M., Blaen P., Krause S. 2020. A Distributed Heat Pulse Sensor Network for Thermo-Hydraulic Monitoring of the Soil Subsurface. Quarterly Journal of Engineering Geology and Hydrogeology. 53. 352-365,https://doi.org/10.1144/qjegh2018-147

Comer-Warner S., Ullah S., Kettridge N., Gooddy D., Krause S. (2019). Seasonal variability of sediment controls on carbon cycling in an agricultural stream. Science of the Total Environment. 688, 732741,https://doi.org/10.1016/j.scitotenv.2019.06.317 
Comer-Warner, S.A., Gooddy, D.C., Ullah, S., Glover L., Kettridge N., Wrexler S.K., Kaiser J., Krause S. 2020. Seasonal variability of sediment controls of nitrogen cycling in an agricultural stream. Biogeochemistry. 148, 31-48 (2020). https://doi.org/10.1007/s10533-020-00644-z

Drake, J.E., Macdonald, C.A., Tjoelker, M.G., Crous, K.Y., Gimeno, T.E., Singh, B.K., Reich, P.B., Anderson, I.C. and Ellsworth, D.S. (2016), Short-term carbon cycling responses of a mature eucalypt woodland to gradual stepwise enrichment of atmospheric $\mathrm{CO}_{2}$ concentration. Glob Change Biol, 22: 380-390. doi:10.1111/gcb.13109

Ellsworth, D.S. (1999), $\mathrm{CO}_{2}$ enrichment in a maturing pine forest: are $\mathrm{CO}_{2}$ exchange and water status in the canopy affected?. Plant, Cell \& Environment, 22: 461-472. doi:10.1046/j.1365-3040.1999.00433.x

Galloway, J.N., Dentener, F.J., Capone, D.G. et al. (2004) Nitrogen Cycles: Past, Present, and Future. Biogeochemistry 70, 153-226. https://doi.org/10.1007/s10533-004-0370-0

Gamage, D.N.V., Biswas, A., Strachan, I.B., Adamchuk, V.I. 2018. Soil Water Measurement Using Actively Heated Fiber Optics at Field Scale. Sensors 18 (4): 1116 DOI: 10.3390/s18041116

Haddad, N.M., Brudvig, L.A., Clobert, J., Davies, K.F., Gonzalez, A., Holt, R.D., Lovejoy, T.E., Sexton, J.O., Austin, M.P., Collins, C.D., Cook, W.M., Damschen, E.I., Ewers, R.M., Foster, B.L., Jenkins, C.N., King, A.J., Laurance, W.F., Levey, D.J., Margules, C.R., Melbourne, B.A., Nicholls, A.O., Orrock, J.L., Song, D.X., Townshend, J.R., 2015. Habitat fragmentation and its lasting impact on Earth's ecosystems. Sci. Adv. 1.https://doi.org/10.1126/sciadv.1500052

Hart, Kris; Curioni, Giulio; Blaen, Philip; Thomas, Rick; Harper, Nicholas; Miles, Peter; Lewin, Keith; Nagy, John; Bannister, Edward; Cai, Xiaoming ; Krause, Stefan; Tausz, Michael; MacKenzie, A. Robert (2019) Characteristics of Free Air Carbon Dioxide Enrichment of a Northern Temperate Mature Forest. Glob Change Biol. doi:10.1111/gcb.14786

Norby, R. J., M. G. De Kauwe, T. F. Domingues, R. A. Duursma, D. S. Ellsworth, D. S. Goll, D. M. Lapola, K. A. Luus, A. R. MacKenzie, B. E. Medlyn, R. Pavlick, A Rammig, B Smith, R Thomas, K Thonicke, A. P. Walker, Xiaojuan Yang, and Sonke Zaehle, Model-data synthesis for the next generation of forest FACE experiments, New Phytologist, 2015, DOI: 10.1111/nph.13593.

Parker, D.E., T.P. Legg, and C.K. Folland. 1992. A new daily Central England Temperature Series, 17721991. Int. J. Clim., Vol 12, pp. 317-342.

Payne, Richard John, Dise, Nancy B., Field, Christopher D et al. (3 more authors) (2017) Nitrogen deposition and plant biodiversity : past, present and future. Frontiers in Ecology and the Environment.https://doi.org/10.1002/fee.1528

Qiu, H., Blaen, P., Comer-Warner, S., Hannah, D. M., Krause, S., \& Phanikumar, M. S. 2019. Evaluating a coupled phenology - surface energy balance model to understand stream - subsurface temperature dynamics in a mixed-use farmland catchment. Water Resources Research, 55.https://oi.org/10.1029/2018WR023644

Rennenberg, H., Dannenmann, M. (2015) Nitrogen nutrition of trees and temperate forests - the significance of nitrogen availability in pedosphere and atmosphere. Forests 6, 2820-2835.

Sommerfeld, A., Senf, C., Buma, B. et al. (2018) Patterns and drivers of recent disturbances across the temperate forest biome. Nat Commun 9, 4355. https://doi.org/10.1038/s41467-018-06788-9

\section{Figure Captions}

Figure 1. (a) BIFoR FACE is located in Mill Haft (white dashed line; lighter patches show locations of the FACE arrays and control patches) in a patchwork of old-growth forest, new forest plantation on arable land, and arable fields. (b) Wood Brook catchment (white dashed line) with the stream running along the northern edge of Mill Haft. (c) Central England location of Mill Haft. 
Figure 2. A schematic view of the sensor deployment and tissue and data flow through BIFoR FACE and Wood Brook. The main experimental infrastructure elements are shown (left); replicates are indicated by "n = ". Data from electronic sensors are recorded in networked field dataloggers and relayed to the facility server. Back-up is carried out on-site and by daily data download to the main University of Birmingham servers with Retrospect software (Retrospect Inc. USA). Initial quality assurance is under the control of the BIFoR Data Manager (author GC) before data is released to the BIFoR FACE community. A parallel system operates for physical samples, the metadata from which enters the BIFoR FACE database via chainof-custody software (Pro-curo Software Ltd, West Sussex, UK).

Figure 3. a) time series of daily top-of-forest precipitation and soil moisture from distributed temperature sensing (DTS) by fibre-optic cable embedded at $10 \mathrm{~cm}$ depth between rows on new broadleaf forest plantation immediately south of the FACE forest (see Figure 1). b) Time series of shallow soil water content from an array of sensors in the FACE forest. The numbers of sensors at each part of the time series are reported in the top of the panel. c) Water level (in blue) and dissolved oxygen (in green) measured on the Wood Brook stream (see Figure 1). 


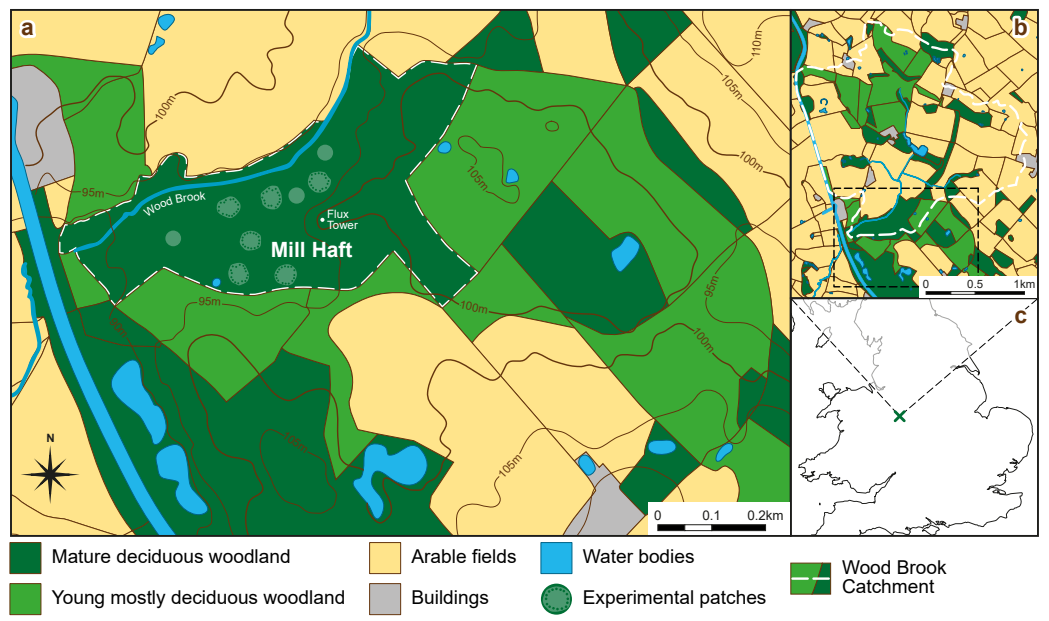



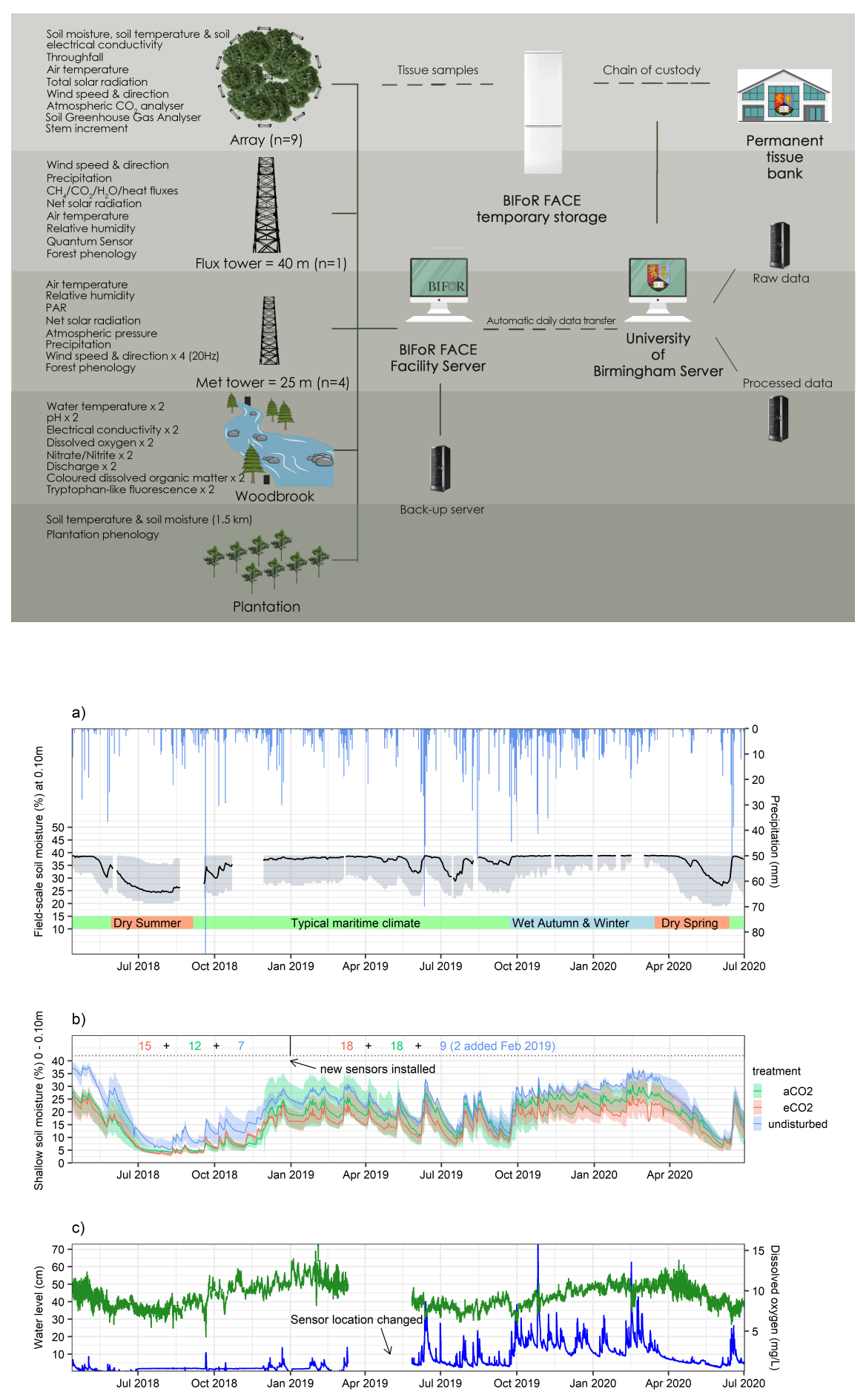